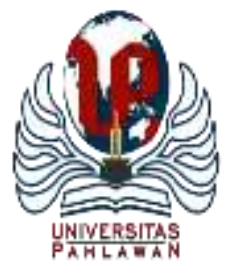

Edukatif : Jurnal Ilmu Pendidikan Volume 3 Nomor 6 Tahun 2021 Halm 4881 - 4888

EDUKATIF: JURNAL ILMU PENDIDIKAN

Research \& Learning in Education

https:/ledukatif.org/index.php/edukatif/index

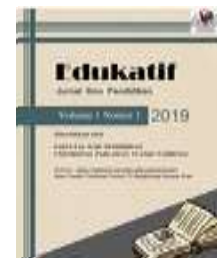

\title{
Pengaruh Mata Pelajaran Kewirausahaan dan Lingkungan Pergaulan terhadap Motivasi Berwirausaha Siswa SMKS Al - Hamidiyah
}

\author{
Benardi $^{1 凶}$, Mohammad Chaidir ${ }^{2}$, Anisa Setyowati ${ }^{3}$ \\ Sekolah Tinggi Ilmu Ekonomi Kasih Bangsa, Indonesia ${ }^{1,2,3}$ \\ E-mail : chenbenardi@gmail.com ${ }^{1}$, chaidir@ mchaidir.com ${ }^{2}$, anisasetyowati246@gmail.com $^{3}$
}

\begin{abstract}
Abstrak
Menanamkan motivasi kepada siswa Sekolah Menengah Kejuruan (SMK) untuk berwirausaha dapat menjadi salah satu suatu upaya dalam mengurangi tingkat pengangguran di Indonesia yaitu melalui pengajaran kewirausahaan kepada siswa. Penelitian ini bertujuan untuk mengetahui pengaruh mata pelajaran kewirausahaan dan lingkungan pergaulan terhadap motivasi berwirausaha siswa SMKS Al - Hamidiyah. Metode penelitian dalam penelitian ini menggunakan pendekatan kuantitatif. Sampel diperoleh dengan menggunakan teknik simpel random sampling yaitu sebanyak 213 siswa dari populasi 338 siswa SMKS AlHamidiyah. Variabel penelitian adalah mata pelajaran kewirausahaan dan lingkungan pergaulan sebagai variabel bebas dengan motivasi berwirausaha sebagai variabel terikat. Pengumpulan data menggunakan kuesioner yang kemudian diolah dengan software SPSS-24. Hasil penelitian menunjukkan bahwa mata pelajaran kewirausahaan dan lingkungan pergaulan mempengaruhi motivasi berwirausaha siswa SMKS Al Hamidiyah dan secara parsial menunjukkan bahwa mata pelajaran kewirausahaan tidak berpengaruh terhadap motivasi berwirausaha, justru lingkungan pergaulan yang memiliki pengaruh terhadap motivasi berwirausaha siswa SMKS A-Hamidiyah.
\end{abstract}

Kata kunci: Kewirausahaan, Lingkungan Pergaulan, Motivasi Berwirausaha.

\begin{abstract}
Instilling motivation in vocational high school students (SMK) to become entrepreneurs can be an effort to reduce the unemployment rate in Indonesia through teaching entrepreneurship to students. This study aims to find out the magnitude of the influence of entrepreneurship subjects and the social environment on the entrepreneurial motivation of SMKS Al - Hamidiyah students. The research method used in this research is quantitative research method. The sample was obtained using simple random sampling with 213 students from a population of 338 students of SMKS Al-Hamidiyah. The variables used in this study are entrepreneurship subjects and the social environment as an independent variable with entrepreneurial motivation as a dependen variabel. Data collection uses a questionnaire then processed using SPSS-24 software. The results showed that entrepreneurship subjects and social environment influenced the entrepreneurial motivation of SMKS Al - Hamidiyah students and partially showed that the subject of entrepreneurship has no effect on entrepreneurial motivation but in fact the social environment has an influence on the entrepreneurial motivation of SMKS A-Hamidiyah students.
\end{abstract}

Keywords: Entrepreneurship Subjects, Social Environment, Entrepreneurial Motivation.

Copyright (c) 2021 Benardi, Mohammad Chaidir,'Anisa Setyowati

$\triangle$ Corresponding author

Email : chenbenardi@gmail.com

DOI : https://doi.org/10.31004/edukatif.v3i6.1376

ISSN 2656-8063 (Media Cetak)

ISSN 2656-8071 (Media Online) 
4882 Pengaruh Mata Pelajaran Kewirausahaan dan Lingkungan Pergaulan terhadap Motivasi Berwirausaha Siswa SMKS Al - Hamidiyah - Benardi, Mohammad Chaidir,,Anisa Setyowati

DOI: https://doi.org/10.31004/edukatif.v3i6.1376

\section{PENDAHULUAN}

Penyebaran Virus Corona (Covid-19) yang semula mewabah di kota Wuhan- China kemudian menyebar ke berbagai belahan dunia dan akhirnya World Health Organization (WHO) mendeklarasikannya sebagai Pandemi Global, telah memberikan dampak yang sangat luas dalam kehidupan masyarakat dunia. Indonesia pun tidak luput dari serangan virus ini yang sejak pertama kali diumumkan secara resmi oleh pemerintah Indonesia, telah terjadi lonjakan pasien positif dan kian meningkat. Kebijakan pembatasan kegiatan masyarakat terpaksa menjadi pilihan yang harus diambil pemerintah untuk menghindari perluasan penyebaran Covid-19 di Indonesia. Pembatasan kegiatan masyarakat tentu saja langsung berdampak pada dunia usaha yang harus menghentikan kegiatannya (kecuali 11 sektor yang dikecualikan). Dunia usaha berupaya untuk mempertahankan kelangsungan hidup dengan melakukan efisiensi yang salah satu langkah yang diambil adalah efisiensi penggunaan tenaga kerja sehingga juga memberi dampak pada peningkatan jumlah pengangguran di Indonesia. Akibat pandemi covid-19, pertumbuhan ekonomi Indonesia yang sejak tahun 2017 konstan di atas 5\%, langsung mengalami kontraksi hingga minus 5,32\% di kuartal kedua tahun 2020. Dan hal ini seiring dengan terjadinya peningkatan pengangguran dari 4,94\% di bulan Februari 2020 menjadi 7,07\% di bulan Agustus 2020 (BPS, 2021).

DKI Jakarta sebagai ibukota negara Indonesia adalah provinsi yang memberikan kontribusi pertumbuhan ekonomi Indonesia terbesar yang juga tidak dapat menghindari dampak penyebaran virus covid19 bahkan menjadi provinsi tertinggi dengan jumlah orang yang terkonfirmasi covid-19. DKI Jakarta berulang kali menetapkan kebijakan pembatasan kegiatan masyarakat sejak bulan Maret 2020 yang berakibat langsung pada peningkatan pengangguran karena dunia usaha yang mengurangi tenaga kerja, atau mengalami kebangkutan atau bahkan menutup usahanya. Badan Pusat Statistik (BPS Provinsi DKI Jakarta, 2020) mencatat tingkat pengangguran terbuka di DKI Jakarta pada bulan Agustus 2020 sebesar 10.95\% dengan lulusan Sekolah Menengah Kejuruan (SMK) mendominasi kontribusi pertumbuhan pengangguran di DKI Jakarta yaitu sebesar 15.40\% (BPS Provinsi DKI Jakarta, 2020). Padahal, Sekolah Menengah Kejuruan (SMK) adalah pendidikan kejuruan tingkat menengah yang mempersiapkan peserta didik untuk bekerja dalam bidang tertentu sebagaimana tertuang dalam penjelasan Undang-Undang No. 20 tahun 2003 pasal 15. Tingginya tingkat pengangguran pada lulusan SMK di DKI Jakarta menunjukkan adanya ketidakseimbangan antara pertumbuhan tenaga kerja dengan pertumbuhan lapangan usaha sehingga terjadi penurunan tingkat kesempatan kerja bagi lulusan SMK yang kemudian diperparah oleh dampak pandemi covid-19. DKI Jakarta menghadapi permasalahan tingginya jumlah pengangguran dari lulusan SMK maka diperlukan penciptaan lapangan usaha baru untuk dapat mengimbangi pertumbuhan tenaga kerja di DKI Jakarta khususnya tenaga kerja terampil dari lulusan SMK. Hal ini dapat dilakukan dengan memotivasi lulusan SMK untuk mau mengubah cara berpikir dari semula sebagai pencari kerja menjadi pencipta kerja sehingga muncul minat berwirausaha yang pada gilirannya akan menurunkan tingkat pengangguran di DKI Jakarta.

Motivasi adalah dorongan dasar yang menggerakkan seseorang bertingkah laku. Dorongan ini berada pada diri seseorang yang menggerakkan untuk melakukan sesuatu yang sesuai dengan dorongan dalam dirinya (Hamzah B. Uno, 2016). Motivasi pada setiap pribadi berbeda antara individu yang satu dengan yang lainnya. Akan hal itu, diperlukan pengetahuan mengenai pengertian dan hakikat motivasi serta kemampuan teknis menciptakan situasi sehingga menimbulkan motivasi atau dorongan bagi mereka untuk berbuat dan berperilaku sesuai apa yang dikehendaki oleh individu lain atau organisasi (Sayu Ketut Sutrisna Dewi, 2017). Motivasi kewirausahaan adalah dorongan seseorang agar mampu menjadi mandiri dan dapat bermanfaat bagi orang lain. Ada banyak motivasi yang mempengaruhi minat berwirausaha, misalnya keinginan untuk dihormati, melanjutkan tradisi keluarga, mendapatkan pendapatan lebih baik, dan lain sebagainya. Motivasi seseorang menjadi wirausaha dibagi dalam tiga dimensi, yaitu ambisi kemandirian (ambition for freedom), 
4883 Pengaruh Mata Pelajaran Kewirausahaan dan Lingkungan Pergaulan terhadap Motivasi Berwirausaha Siswa SMKS Al - Hamidiyah - Benardi, Mohammad Chaidir,,Anisa Setyowati

DOI: https://doi.org/10.31004/edukatif.v3i6.1376

realisasi diri (self-realisation) dan faktor pendorong (pushing factors) (Urve Venesaar \& Ene Kolbre \& Toomas Piliste, 2006).

Dorongan atau ketertarikan untuk berwirausaha umumnya muncul karena keinginan dari diri sendiri. Berwirausaha akan mendorong motivasi untuk memperoleh imbalan dalam bentuk laba atau keuntungan, kebebasan, impian personal dalam diri untuk mewujudkannya, kemandirian dalam menciptakan peluang pengembangan usaha dan kemampuan mengelolanya (Arif Yusuf Hamali, 2017). Wirausaha merupakan seseorang yang berani melakukan usaha secara mandiri yang memaksimalkan seluruh sumber daya dan upaya dalam menganalisa produk baru, menentukan cara melakukan produksi baru, mengatur operasi pengadaan produk baru, memperluas pangsa pasar, dan mengelola modal operasi agar produk yang dihasilkan memiliki nilai yang tinggi (M.Anang Firmansyah, 2020). Keberanian seseorang dalam berwirausaha didukung oleh orang yang berada di lingkungan terdekatnya seperti guru, dosen atau koperasi yang memberikan pengajaran kewirausahaan. Wirausaha adalah orang yang mampu melihat peluang dan berupaya untuk meraih peluang tersebut. Terdapat 3 faktor untuk memulai usaha yaitu personal, sosiologi dan lingkungan (William D. Bygrave, 2010). Untuk siswa SMK lingkungan pergaulan adalah media dalam bersosialisasi dan menjadi lingkungan kedua setelah lingkungan keluarga yang dapat memberikan dampak positif diantaranya semangat, inovatif, dan kreatif untuk menjadi wirausaha. Siswa SMK memperoleh mata pelajaran kewirausahaan agar mampu melihat peluang-peluang bisnis yang ada di masyarakat dan menciptakan kreativitas untuk meraih peluang tersebut dengan berwirausaha. Mata pelajaran ini merupakan bagian dari mata pelajaran wajib di lingkungan Sekolah Menengah Kejuruan yang dapat mendorong siswa lulusan SMK termotivasi untuk berani berwirausaha. Hal ini sejalan dengan penelitian Annauval \& Ghofur (2021) bahwa hasil belajar ekonomi dipengaruhi oleh lingkungan keluarga dan motivasi belajar secara bersama-sama.

Berdasarkan uraian diatas maka dapat dilakukan penelitian bagaimana pengaruh mata pelajaran kewirausahaan dan lingkungan pergaulan terhadap motivasi berwirausaha. Penelitian ini bertujuan untuk mengetahui bagaimana pengaruh mata pelajaran kewirausahaan dan lingkungan pergaulan pada siswa SMK yang berada di wilayah DKI Jakarta yaitu SMKS Al-Hamidiyah. Hasil penelitian diharapkan dapat menjadi referensi bagi manajemen dan guru Sekolah Menengah Kejuruan, orangtua, serta pemerintah dalam upaya menekan tingkat pertumbuhan pengangguran terbuka DKI Jakarta yang berasal dari lulusan SMK.

\section{METODE PENELITIAN}

Metode penelitian dalam penelitian ini menggunakan pendekatan kuantitatif untuk menguji pengaruh mata pelajaran kewirausahaan dan lingkungan pergaulan terhadap motivasi berwirausaha di SMKS AlHamidiyah. Data dikumpulkan menggunakan kuestioner dimana variabel motivasi berwirausaha dibagi menjadi 3 (tiga) dimensi yaitu Ambition of Freedom, Self Realisation dan Pushing. Faktor sebagai teori yang mendasari penyusunan instrumen penelitian. Variabel penelitian adalah mata pelajaran kewirausahaan dan lingkungan pergaulan sebagai variabel bebas dengan motivasi berwirausaha sebagai variabel terikat.

Pengumpulan data dilakukan dengan menggunakan kuestioner. Kuesioner merupakan teknik pengumpulan data yang dilakukan dengan cara memberi seperangkat pertanyaan atau pernyataan tertulis kepada responden untuk dijawabnya (Sugiyono, 2011). Kuestioner disusun dengan menggunakan skala Guttman sehingga diperoleh jawaban yang tegas dari responden yaitu angka 1 untuk pilihan jawaban setuju dan 0 untuk pilihan jawaban tidak setuju. Sampel ditentukan dengan menggunakan teknik simpel random sampling sehingga diperoleh 213 siswa dari populasi 338 siswa SMKS Al-Hamidiyah. Hasil pengumpulan data kemudian diolah menggunakan bantuan software SPSS-24 untuk memperoleh jawaban bagaimana pengaruh mata pelajaran kewirausahaan dan lingkungan pergaulan terhadap motivasi berwirausaha siswa SMKS Al-Hamidiyah. Analisa data penelitian menggunakan analisis regresi linier berganda yang diawali dengan melakukan terlebih dahulu uji validitas dan uji reliabilitas terhadap kuestioner penelitian. Kemudian 
4884 Pengaruh Mata Pelajaran Kewirausahaan dan Lingkungan Pergaulan terhadap Motivasi Berwirausaha Siswa SMKS Al - Hamidiyah - Benardi, Mohammad Chaidir,,Anisa Setyowati

DOI: https://doi.org/10.31004/edukatif.v3i6.1376

dilanjutkan uji asumsi klasik yang terdiri dari uji normalitas, uji heteroskedastisitas, uji multikolinieritas dan uji autokorelasi untuk memperoleh data penelitian yang Best Linear Unbias dan Estimate (BLUE) guna menguji hipotesis. Menurut Imam Ghozali (Ghozali, 2011) model regresi dikatakan berdistribusi normal jika data ploting mengikuti garis diagonal, dan tidak terjadi gejala multikolinieritas jika nilai tolerance lebih besar dari 0,1 dan nilai VIF lebih kecil dari 10, kemudian dikatakan tidak terjadi heteroskedastisitas jika tidak ada pola yang jelas (bergelombang melebar kemudian menyempit) pada gambar scatterplots serta titik-titik menyebar diatas dan dibawah angka 0 pada sumbu y, serta uji autokorelasi dilakukan untuk menguji apakah dalam model regresi linier terdapat korelasi antara kesalahan pengganggu pada suatu periode dengan kesalahan pengganggu pada periode sebelumnya. Uji autokorelasi dilakukan untuk data time series, maka sehubungan penelitian ini tidak menggunakan data time series maka tidak dilakukan uji autokorelasi.

Setelah uji asumsi klasik dilakukan dan terpenuhi data yang BLUE maka selanjutnya dilakukan uji hipotesis penelitian ini yaitu $\mathrm{H}_{\mathrm{ol}}=$ mata pelajaran kewirausahaan tidak berpengaruh terhadap motivasi berwirausaha; $\mathrm{H}_{\mathrm{a} 1}=$ mata pelajaran kewirausahaan berpengaruh terhadap motivasi berwirausaha; $\mathrm{H}_{02}=$ lingkungan pergaulan tidak berpengaruh terhadap motivasi berwirausaha; $\mathrm{H}_{\mathrm{a} 2}=$ lingkungan pergaulan berpengaruh terhadap motivasi berwirausaha.

\section{HASIL DAN PEMBAHASAN PENELITIAN}

Menurut Sugiyono (Sugiyono, 2018) validitas adalah suatu ukuran yang menunjukan derajat ketepatan antara data yang sesungguhnya terjadi pada objek dengan data yang dikumpulkan oleh peneliti (Sugiyono, 2018:125). Uji validitas penelitian ini dilakukan dengan menggunakan tingkat kepercayaan 5\% dan kemudian dilanjutkan dengan uji reliabilitas serta uji asumsi klasik sebelum dilakukan uji hipotesis agar diperoleh data penelitian yang BLUE.

\section{a. Uji Validitas}

Tabel 1. Hasil Pengujian Validitas

\begin{tabular}{cccc}
\hline \multicolumn{1}{l}{ Variabel/Item } & $\mathbf{R}_{\text {hitung }}$ & $\mathbf{R}_{\text {tabel }}$ & Keterangan \\
\hline \multicolumn{1}{l}{ Mata pelajaran Kewirausahaan (X1) } & & \\
\hline X1.1 & 0,485 & 0,138 & Valid \\
\hline X1.2 & 0,516 & 0,138 & Valid \\
\hline X1.3 & 0,523 & 0,138 & Valid \\
\hline X1.4 & 0,548 & 0,138 & Valid \\
\hline X1.5 & 0,401 & 0,138 & Valid \\
\hline X1.6 & 0,366 & 0,138 & Valid \\
\hline Lingkungan Pergaulan (X2) & & & \\
\hline X2.1 & 0,594 & 0,138 & Valid \\
\hline X2.2 & 0,695 & 0,138 & Valid \\
\hline X2.3 & 0,394 & 0,138 & Valid \\
\hline X2.4 & 0,667 & 0,138 & Valid \\
\hline X2.5 & 0,314 & 0,138 & Valid \\
\hline X2.6 & 0,479 & 0,138 & Valid \\
\hline Motivasi Kewirausahaan (Y) & & & \\
\hline Y1 & 0,226 & 0,138 & Valid \\
\hline Y2 & 0,729 & 0,138 & Valid \\
\hline Y3 & 0,716 & 0,138 & Valid \\
\hline Y4 & 0,741 & 0,138 & Valid \\
\hline Y5 & 0,266 & 0,138 & Valid
\end{tabular}




Y6 $\quad 0,223 \quad 0,138 \quad$ Valid

Uji validitas dilakukan dengan membandingkan nilai $R_{\text {hitung }}$ dengan $R_{\text {tabel. }}$ Jika nilai $r_{\text {hitung }}$ lebih besar dari $R_{\text {tabel }}\left(R_{\text {hitung }}>R_{\text {tabel }}\right)$ dan bernilai positif maka variabel dikatakan valid sedangkan jika sebaliknya maka variabel tidak valid (Ghozali, 2011). Nilai $R_{\text {tabel }}$ data penelitian ini adalah 0,138 dan hasil pengujian validitas menunjukkan nilai $\mathrm{R}_{\text {hitung }}$ lebih besar dari 0,138 yaitu antara 0,22 sampai dengan 0,74 maka instrumen penelitian dinyatakan valid.

\section{b. Uji Reliabilitas}

Setelah kuestioner dinyatakan valid, selanjutnya dilakukan uji realibitas untuk mengetahui apakah kuestioner memiliki konsistensi jika pengukuran dilakukan secara berulang. Uji reliabilitas diukur dengan nilai Cronbach Alfa yaitu kuestioner dikatakan reliabel jika memiliki nilai lebih besar dari 0,6 (Sujarweni, 2016). Dari hasil pengolahan data penelitian, diperoleh nilai Cronbach Alfa sebesar 0,699.

Tabel 2. Uji Reliabilitas

\begin{tabular}{rr}
\hline $\begin{array}{c}\text { Cronbach's } \\
\text { Alpha }\end{array}$ & N of Items \\
\hline .699 & 18 \\
\hline
\end{tabular}

\section{c. Uji Asumsi Klasik}

Uji asumsi klasik dilakukan untuk memperoleh data penelitian yang BLUE yaitu uji normalitas, heteroskedastisitas, dan multikolinearitas dengan hasil sebagai berikut :

1) Uji Normalitas

Hasil pengolahan data penelitian terlihat pada gambar 1 dimana titik-titik data penelitian mengikuti garis diagonal, maka model regresi penelitian berdistribusi normal.

2) Uji Heteroskedastisitas

Hasil pengolahan data menghasilkan gambar scatterplot yang membentuk titik-titik menyebar diatas dan dibawah angka 0 pada sumbu y yang tidak memiliki pola maka tidak terjadi heteroskedastisitas.

3) Uji Multikolinieritas

Hasil pengolahan data menunjukkan nilai tolerance 0,896 yang berarti lebih besar dari 0,1 dan nilai VIF 1,116 yang lebih kecil dari 10. Maka model regresi penelitian ini tidak terjadi gejala multikolinieritas.

\section{d. Uji Hipotesis}

Dengan telah terpenuhinya uji validitas, uji reliabilitas yang menunjukkan instrumen kuestioner adalah valid dan reliabel dan terpenuhinya uji asumsi klasik maka dilanjutkan uji hipotesis dengan menggunakan uji$\mathrm{T}$ untuk menguji pengaruh variabel penelitian secara parsial dan uji-F untuk menguji variabel penelitian secara bersama-sama (simultan) variabel mata pelajaran kewirausahaan (X1) dan lingkungan pergaulan (X2) terhadap motivasi berwirausaha (Y). Uji-T parsial dalam analisa linear berganda berdasarkan signifikansi menurut Imam Ghozali (Ghozali, 2011) adalah jika nilai signifikansi dari hasil pengolahan data lebih kecil dari 0,05 maka artinya variabel independen berpengaruh terhadap variabel dependen dan jika sebaliknya maka variabel penelitian tidak berpengaruh. Selain itu uji parsial dapat dilihat berdasarkan perbandingan nilai $t_{\text {hitung }}$ dan $t_{\text {tabel. }}$. Menurut (Sujarweni, 2016) jika nilai thitung lebih besar dari tabel maka artinya variabel independen berpengaruh secara parsial terhadap variabel independen, demikian sebaliknya. Sedangkan Uji - F digunakan untuk 
4886 Pengaruh Mata Pelajaran Kewirausahaan dan Lingkungan Pergaulan terhadap Motivasi Berwirausaha Siswa SMKS Al - Hamidiyah - Benardi, Mohammad Chaidir,,Anisa Setyowati

DOI: https://doi.org/10.31004/edukatif.v3i6.1376

menguji pengaruh variabel independen terhadap dependen secara bersama-sama (simultan). Hasil pengolahan data penelitian menggunakan SPSS, diperoleh hasil sebagai berikut :

Tabel 3. Uji Hipotesis - Parsial

\begin{tabular}{|c|c|c|c|c|c|c|c|c|}
\hline \multicolumn{9}{|c|}{ Coefficients $^{\mathrm{a}}$} \\
\hline \multirow{4}{*}{\multicolumn{2}{|c|}{ Model }} & \multirow{3}{*}{\multicolumn{2}{|c|}{$\begin{array}{c}\text { Unstandardized } \\
\text { Coefficients }\end{array}$}} & \multirow{4}{*}{$\begin{array}{c}\text { Standardize } \\
\text { d } \\
\text { Coefficients } \\
\text { Beta }\end{array}$} & \multirow{5}{*}{$\frac{\mathrm{t}}{3.676}$} & \multirow{5}{*}{$\begin{array}{l}\text { Sig. } \\
.000\end{array}$} & \multirow{3}{*}{\multicolumn{2}{|c|}{$\begin{array}{l}\text { Collinearity } \\
\text { Statistics }\end{array}$}} \\
\hline & & & & & & & & \\
\hline & & & & & & & & \\
\hline & & B & Std. Error & & & & $\begin{array}{c}\text { Toleranc } \\
\mathrm{e}\end{array}$ & VIF \\
\hline 1 & (Constant & 1.820 & .495 & & & & & \\
\hline & totalx 1 & .076 & .081 & .062 & .941 & .348 & .896 & 1.116 \\
\hline & totalx2 & .470 & .075 & .412 & 6.280 & .000 & .896 & 1.116 \\
\hline
\end{tabular}

Uji t digunakan untuk menunjukkan seberapa jauh pengaruh satu variabel independen secara individual terhadap variabel dependen. Pengujian ini dilakukan dengan membandingkan nilai $t_{\text {hitung }}$ dengan $t_{\text {tabel }}$. Nilai $t$ tabel dicari pada signifikansi $0,05(\alpha / 2=0.025$; $\mathrm{df})$ dengan derajat kebebasan $\mathrm{df}=\mathrm{n}-\mathrm{k}-1$ atau 213-3-1 $=209$ dan hasil yang diperoleh untuk nilai t-tabel sebesar 1,971.

1) Berdasarkan hasil pengujian hipotesis dapat dilihat bahwa variabel mata pelajaran kewirausahaan memiliki nilai t-hitung sebesar 0,941. Ini menunjukkan bahwa thitung lebih kecil dari tabel yaitu $0,941<1,971$. Jika dilihat dari tingkat signifikansi dalam tabel, variabel mata pelajaran kewirausahaan memiliki tingkat signifikansi sebesar 0,348 yang berarti lebih besar dari 0,05. Maka hasil penelitian ini menunjukkan bahwa mata pelajaran kewirausahaan tidak berpengaruh terhadap motivasi berwirausaha pada siswa SMKS Al-Hamidiyah.

2) .Sedangkan pada variabel lingkungan pergaulan memiliki nilai $t_{\text {hitung }}$ sebesar 6,280. Hal ini menunjukkan bahwa $t_{\text {hitung }}$ lebih besar dari $t_{\text {tabel }}$ yaitu $6,280>1,971$. Dan jika dilihat dari tingkat signifikansi yang terlihat pada tabel diatas, variabel lingkungan pergaulan memiliki tingkat signifikansi sebesar 0,000 yang berarti lebih kecil dari 0,05. Maka hasil penelitian ini menunjukkan bahwa lingkungan pergaulan berpengaruh terhadap motivasi berwirausaha pada siswa SMKS Al-Hamidiyah.

Untuk uji F terlihat pada tabel hasil pengolahan SPSS pada tabel Anova dibawah ini

Tabel 4. Uji Hipotesis - Simultan

\begin{tabular}{llrrrrr}
\hline \multicolumn{7}{c}{ ANOVA $^{\text {a }}$} \\
\hline \multirow{2}{*}{ Model } & \multicolumn{7}{c}{$\begin{array}{l}\text { Sum of } \\
\text { Squares }\end{array}$} & df & Mean Square & F & Sig. \\
\hline \multirow{2}{*}{1} & Regression & 53.928 & 2 & 26.964 & 24.620 & $.000^{\mathrm{b}}$ \\
\cline { 2 - 8 } & Residual & 229.996 & 210 & 1.095 & & \\
\cline { 2 - 7 } & Total & 283.925 & 212 & & & \\
\hline
\end{tabular}

Uji $\mathrm{F}$ digunakan untuk menunjukkan pengaruh variabel independen secara bersama-sama terhadap variabel dependen. Pengujian ini dilakukan dengan membandingkan nilai $\mathrm{F}_{\text {hitung }}$ dengan $\mathrm{F}_{\text {tabel }}$. Nilai F-tabel dicari pada nilai $(\mathrm{k} ; \mathrm{n}-\mathrm{k})$ yaitu $(3 ; 210)$ dan hasil yang diperoleh untuk nilai F-tabel sebesar 2,65. Dari hasil pengolahan data mengggunakan SPSS terlihat pada tabel Anova, nilai $\mathrm{F}_{\text {hitung }}$ adalah sebesar 24,620 dengan nilai Signifikansi sebesar 0,000. Maka nilai $F_{\text {hitung }}$ lebih besar dari $F_{\text {tabel }}$ atau 24,620 > 2,65 dan nilai signifikan $0,000<0,05$ yang berarti secara simultan mata pelajaran kewirausahaan dan lingkungan pergaulan berpengaruh terhadap motivasi berwirausaha pada siswa SMKS Al-Hamidiyah. 
Berdasarkan hasil pengujian diatas diketahui bahwa mata pelajaran kewirausahaan di SMKS AlHamidiyah tidak berpengaruh secara langsung dalam menumbuhkan motivasi berwirausaha siswa. Hal ini menunjukkan bahwa mata pelajaran kewirausahaan diikuti siswa sebagai kewajiban kurikulum tapi kurang dapat memotivasi siswa berwirausaha. Seharusnya mata pelajaran kewirausahaan menjadi tittik awal siswa memahami perbedaan berwirausaha dan sebagai pekerja sehingga diharapkan tumbuh motivasi untuk berwirausaha. Berbeda halnya jika pembelajaran kewirausahaan diberikan di tingkat perguruan tinggi dimana beberapa penelitian menunjukkan bahwa mata kuliah kewirausahaan di perguruan tinggi berpengaruh terhadap motivasi mahasiswa berwirausaha seperti penelitian yang dilakukan oleh Suwarso (2018) terhadap mahasiswa di Jember - Jawa Timur dan penelitian (Sinarasri \& Hanum, 2012) terhadap mahasiswa Unimus di Semarang. Sedangkan pada variabel lingkungan pergaulan, hasil penelitian ini menunjukkan bahwa lingkungan pergaulan berpengaruh terhadap motivasi siswa SMKS Al-Hamidiyah berwirausaha. Keberadaan peserta didik siswa bersama lingkungan pergaulan yang semakin intensif dan sering ternyata menunjukkan pengaruhnya pada motivasi berwirausaha baik pada siswa ditingkat SMK maupun perguruan tinggi sebagaimana hasil penelitian yang dilakukan oleh (Tammie et al., 2019) terhadap siswa kelas XII SMKN 1 di Cimahi, penelitian (Indah Utama \& Syaiful, 2020) terhadap siswa kelas XI jurusan tata niaga SMKN 1 di Jambi dan penelitian (Syarifuddin et al., 2017) terhadap mahasiswa Sekolah Tinggi Pariwisata ARS Internasional di Bandung. Selanjutnya hasil penelitian ini menunjukkan bahwa variabel penelitian yaitu mata pelajaran kewirausahaan dan lingkungan pergaulan secara bersama-sama (simultan) berpengaruh terhadap motivasi berwirausaha.

Maka dari penelitian ini dapat diketahui bahwa motivasi siswa SMKS Al-Hamidiyah untuk berwirausaha akan meningkat jika mata pelajaran kewirausahaan dapat bersinergi dengan aktivitas terkait dalam lingkungan pergaulan siswa SMK. Hal ini sejalan dengan hasil penelitian Ida Yulianti, (2019) yang menyatakan bahwa mata pelajaran kewirausahaan dan motivasi siswa berpengaruh pada minat berwirausaha. Maka dari hasil penelitian ini yang menunjukkan bahwa terdapat pengaruh mata pelajaran kewirausahaan dan lingkungan pergaulan dengan motivasi berwirausaha diharapkan akan berdampak pada perubahan pola pikir lulusan SMK yang semua sebagai pencari kerja menjadi pencipta kerja yang justru akan menyerap sumber daya manusia sehingga sangat memungkinkan untuk mengurangi pengangguran. Dampak positif ini dapat menciptakan berbagai kesempatan kerja baik pada usaha yang dirintis lulusan SMK ataupun dampak perekonomian disekitar usaha tersebut sehingga pada gilirannya akan mengurangi jumlah pengangguran. Hasil penelitian ini sejalan dengan hasil penelitian yang dilakukan sebelumnya (Azira Prawinugraha, Muhammad Jamil Latief, 2021).

\section{KESIMPULAN}

Penelitian ini bertujuan untuk mengetahui pengaruh mata pelajaran kewirausahaan dan lingkungan pergaulan terhadap motivasi berwirausaha pada siswa SMKS Al - Hamidiyah. Penelitian ini diperoleh dengan melakukan penyebaran kuesioner kepada siswa SMKS Al - Hamidiyah yang kemudian diolah dengan menggunakan software SPSS-24. Berdasarkan hasil uraian diatas dengan memperhatikan hasil pengolahan data menggunakan software SPSS-24, dapat disimpulkan bahwa mata pelajaran kewirausahaan dan lingkungan pergaulan memiliki pengaruh terhadap motivasi berwirausaha siswa SMKS Al - Hamidiyah.

Berdasarkan hasil penelitian, mata pelajaran kewirausahaan tidak berpengaruh terhadap motivasi berwirausaha, justru lingkungan pergaulan yang memiliki pengaruh terhadap motivasi berwirausaha siswa SMKS Al - Hamidiyah. Hal ini menunjukan bahwa menanamkan motivasi berwirausaha kepada siswa SMKS $\mathrm{Al}$ - Hamidiyah harus dimulai dari membangun lingkungan pergaulan yang kondusif yang didukung dengan mata pelajaran berwirausaha yang diberikan di kurikulum pembelajaran sekolah. 
4888 Pengaruh Mata Pelajaran Kewirausahaan dan Lingkungan Pergaulan terhadap Motivasi Berwirausaha Siswa SMKS Al - Hamidiyah - Benardi, Mohammad Chaidir,Anisa Setyowati

DOI: https://doi.org/10.31004/edukatif.v3i6.1376

\section{DAFTAR PUSTAKA}

Annauval, A. R., \& Ghofur, M. A. (2021). Lingkungan Keluarga Dan Motivasi Belajar Terhadap Hasil Belajar Mata Pelajaran Ekonomi Pada Pembelajaran Daring. Jurnal Ilmu Pendidikan, 3(5), 2114-2122. Https://Doi.Org/: Https://Doi.Org/10.31004/Edukatif.V3i5.761

Arif Yusuf Hamali, E. S. B. (2017). Pemahaman Kewirausahaan: Strategi Mengubah Pola Pikir "Orang Kantoran" Menuju Pola Pikir "Wirausahawan" Sukses. Kencana.

Azira Prawinugraha $\square$, Muhammad Jamil Latief, S. (2021). Pendidikan Kewirausahaan Berbasis Kearifan Lokal Sumberdaya Kelautan Dan Perikanan. Jurnal Ilmu Pendidikan, 3(5), 3035-3048. Https://Doi.Org/Https://Doi.Org/10.31004/Edukatif.V3i5.1084

BPS. (2021). Berita Resmi Statistik Triwulan 1-2021, 5 Mei 2021.

BPS Provinsi DKI Jakarta. (2020). Keadaan Ketenagakerjaan Provinsi DKI Jakarta Agustus 2020 (Issue 22).

Ghozali, I. (2011). Aplikasi Analisis Multivariate Dengan Program IBM SPSS 19. Semarang: Badan Penerbit Universitas Diponegoro.

Hamzah B. Uno. (2016). Teori Motivasi Dan Pengukurannya Analisis Di Bidang Pendidikanno Title. PT Bumi Aksara.

Ida Yulianti. (2019). Pengaruh Mata Pelajaran Kewirausahaan Dan Motivasi Siswa Terhadap Minat Berwirausaha Siswa Kelas XI Di SMK Muhammadiyah Salaman Kabupaten Magelang. Jurnal Pendidikan Ekonomi, 8(2).

Indah Utama, T., \& Syaiful, S. (2020). Pengaruh Intensitas Pergaulan Teman Sebaya, Sikap, Dan Efikasi Diri Terhadap Jiwa Berwirausaha Siswa Kelas Xi Jurusan Tata Niaga Smkn 1 Kota Jambi. Jurnal Manajemen Pendidikan Dan Ilmu Sosial, 1(2), 422-436. Https://Doi.Org/10.38035/Jmpis.V1i2.280

M.Anang Firmansyah, A. R. (2020). Kewirausahaan (Dasar Dan Konsep). Qiara Media, Pasuruan.

Sayu Ketut Sutrisna Dewi. (2017). Konsep Dan Pengembangan Kewirausahaan Di Indonesia. Deepublish.

Sinarasri, A., \& Hanum, A. N. (2012). Pengaruh Latar Belakang Pendidikan Terhadap Motivasi Kewirausahaan Mahasiswa (Studi Kasus Pada Mahasiswa Unimus Di Semarang). Lppm Unimus, 342 352.

Sugiyono. (2011). Metode Penelitian Kuantitatif Dan Kualitatif Dan R\&D. Bandung: CV. Alfabeta.

Sugiyono. (2018). Metode Penelitian Kuantitatif. Bandung: Alfabeta.

Sujarweni, V. W. (2016). Kupas Tuntas, Penelitian Akuntansi Dengan SPSS. Yogyakarta: Pustaka Baru Press.

Suwarso. (2018). Pengaruh Mata Kuliah Kewirausahaan Dan Pengantar Bisnis Terhadap Motivasi Dan Minat Wirausaha (Study Kasus Mahasiswa Akademi Akuntansi Pgri Jember). Jurnal Manajemen Dan Bisnis Indonesia, 4(2), 98. Https://Doi.Org/10.32528/Jmbi.V4i2.1755

Syarifuddin, D., Iskandar, I., \& Hakim, L. (2017). Dampak Lingkungan Terhadap Minat Mahasiswa Pariwisata $\quad$ Berwirausaha. $\quad$ Pariwisata, $\quad I V(1), \quad 1-13$. Http://Ejournal.Bsi.Ac.Id/Ejurnal/Index.Php/Jp/Article/View/1831/1380

Tammie, R. A., Nuryanti, B. L., \& Utama, R. D. H. (2019). Lingkungan Kewirausahaan Dalam Motivasi Berwirausaha. Journal Of Business Management Education (JBME), 4(1), 34-48. Https://Doi.Org/10.17509/Jbme.V4i1.16194

Urve Venesaar \& Ene Kolbre \& Toomas Piliste. (2006). Students A- Attitudes And Intentions Toward Entrepreneurship At Tallinn University Of Technology.

William D. Bygrave, A. Z. (2010). The Portable MBA In Entrepreneurship (4th Edition (Ed.)). 